\title{
Multiple gene analyses of caligid copepods indicate that the reduction of a thoracic appendage in Pseudocaligus represents convergent evolution
}

\author{
Mark A Freeman ${ }^{1 *}$, Hilal Anshary ${ }^{2}$ and Kazuo Ogawa ${ }^{3}$
}

\begin{abstract}
Background: The Caligidae is a family of parasitic copepods containing over 30 recognised genera. They are commercially important parasites as they cause disease in numerous finfish aquaculture facilities globally. Morphological features are used to distinguish between the genera and Pseudocaligus has traditionally been differentiated from Caligus solely by the presence of a much reduced form of the fourth thoracic leg. Currently there are numerous DNA sequences available for Caligus spp. but only the type species, Pseudocaligus brevipedis, has molecular data available, so systematic studies using molecular phylogenetic analyses have been limited.

Methods: Three gene regions, SSU rDNA, 165 and CO1, for Pseudocaligus fugu from puffer fish from Japan and Pseudocaligus uniartus from rabbit fish from Indonesia are sequenced and molecular phylogenetic analyses performed in order to infer phylogenetic relationships between Pseudocaligus and other caligid copepods.

Results: The analysis revealed that there was no discrete grouping of Pseudocaligus spp. and that they had a polyphyletic distribution within Caligus taxa. Pseudocaligus fugu grouped with Caligus elongatus and contained a unique synapomorphy in the SSU rDNA region only seen in members of that clade. Pseudocaligus uniartus formed a well-supported group, in the SSU rDNA analyses, with a Caligus sp. that also infects rabbit fish, but was unresolved in the other analyses. Pseudocaligus brevipedis consistently and robustly grouped with Caligus curtus and C. centrodonti in all analyses. The majority of Lepeophtheirus spp. form a monophyletic sister group to the Caligus clade; however, L. natalensis is unresolved in all analyses and does not form part of the main Lepeophtheirus clade.

Conclusions: These findings do not support the morphological-based distinction between Pseudocaligus and Caligus, suggesting that the reduced fourth leg is a feature that has evolved on multiple occasions throughout caligid evolution. Congruent molecular phylogenetic data support groupings based on the presence of morphological features, such as lunules, geography and host fish type rather than appendage morphology. Therefore, we support the synonymy of Pseudocaligus with Caligus.
\end{abstract}

Keywords: Pseudocaligus, Caligus, Convergent evolution, Caligidae, Appendage reduction, Lepeophtheirus, Synapomorphy

\footnotetext{
* Correspondence: mark@um.edu.my

${ }^{1}$ Institute of Ocean and Earth Sciences, University of Malaya, Kuala Lumpur, Malaysia

Full list of author information is available at the end of the article
} 


\section{Background}

Parasitic copepods belonging to the family Caligidae are dorso-ventrally flattened ectoparasites that feed on the epithelium and blood of marine and brackish water fishes $[1,2]$ but are also found on other marine animals such a whales [3]. They have the same general body plan consisting of a rounded cephalothoracic shield which is comprised of the head fused with four thoracic segments, a free fourth pedigerous segment, a genital complex and abdomen [1]. The presence or absence of features such as lunules and posterior sinuses, or the morphology of other features like the fourth pediger, genital complex, and the fourth leg are currently used to differentiate between the genera [2]. Some features such as the size of the fourth leg are extremely plastic within the group, ranging from totally absent (Markevichus), to vestigial (Alebion, Pseudocaligus, Pseudolepeophtherius) or well developed (most other genera) [4].

The Caligidae are globally important parasites that are collectively referred to as sea lice, and cause significant disease problems in marine aquaculture worldwide. They can affect fish health and growth rates due to their feeding activities, which causes skin lesions that lead to osmotic regulatory problems and eventually to mortalities [5]. In salmon farms, Lepeophtheirus salmonis infecting fish in Europe and Caligus rogercrosseyi infecting fish in Chile have caused significant losses with numerous treatments being required to effectively control their populations $[6,7]$. It has been estimated that the global annual cost attributed to sea lice infections, in salmonid aquaculture alone, was greater than 300 million Euros in 2006, which constitutes an average of $6 \%$ of the value of production for the countries affected by such infestations [8]. However, these estimates do not take into consideration the additional costs to the environment associated with the use of chemical parasiticides or welfare aspects concerning the fish, farm staff and ultimately the consumer.

Caligids from the genus Pseudocaligus have not been widely reported as being pathogenic to farmed fish. However, recently $P$. fugu has been reported to cause skin lesions in farmed tiger puffer, Takifugu rubripes, in Japan $[9,10]$ and $P$. uniartus is causing serious disease outbreaks in the developing aquaculture of rabbit fish, Siganus spp. in the Philippines [11] and more recently Indonesia. Pseudocaligus spp. have been described as taxonomically distinct from other sea lice, such as Caligus, as they have a significantly reduced fourth leg, which is well developed in most other caligids. However, numerous researchers have questioned the validity of Pseudocaligus as a genus $[1,12,13]$ and a recent review on caligid systematics, based on morphological features, concluded that Pseudocaligus should be treated as a junior synonym of Caligus [14], with the nomenclatural revisions arising from that decision clarified by Özak et al. [15]. However, throughout this manuscript we refer to members of the recently synonymised genus Pseudocaligus for reasons of clarity.

Currently, there is a paucity of DNA sequence data available for pseudocaligid taxa, with the majority of molecular phylogenetic studies of caligids focusing on the genera Caligus and Lepeophtheirus [12,16]. In the present study, we aim to provide additional DNA sequences for $P$. fugu and P. uniartus and include these in molecular phylogenetic studies of the Caligidae.

\section{Methods}

Pseudocaligus uniartus were collected from naturally infected rabbit fish, Siganus guttatus, reared in the Marine Research Station located in Barru Regency, South Sulawesi and $P$. fugu were obtained from naturally infected tiger puffer, Takifugu rubripes in Nagasaki Public Corporation, Japan. DNA samples were analysed from 4 individuals of $P$. uniartus and 3 individuals from $P$. fugu, which had been preserved in $70 \%$ ethanol. The DNA was extracted from whole copepods using QIAamp DNA Mini Kit (Qiagen Inc., Hilden, Germany) following the manufacturer's tissue protocol. DNA was eluted in water and stored frozen at $-20^{\circ} \mathrm{C}$ prior to PCR amplification.

\section{PCR and sequencing}

The target regions for PCR amplification were the small subunit ribosomal DNA (SSU rDNA) and the mitochondria genes CO1 and 16S ribosomal RNA gene. The oligonucleotide primers used to amplify the target regions were: SSU rDNA universal primers 390fwd (5-AGAGGGAGCCTG AGAAACG-3), 870rev (5-GTTGAGTCAAATTAAGCCG CA-3), 870fwd (5-TGCGGCTTAATTTGACTCAAC-3) and 18gM (5-CTTCCGCTGGTTC-ACCTACG-3) [10,17] to get nucleotide sequences of around $1300 \mathrm{bp}$. In addition, to obtain more complete sequence reads, a specific reverse primer was designed (Pcalrev: 5-CCTCCAATTGTTCCT CGTT-3) in conjunction with the forward 18e universal primer (5 CTGGTTGATTCTGCCAGT 3) [18]; 16S primers 16ceoioiF (5-GCCTGTTTATCAAAGACATA-3) and 16ceoioiR (5-ATAGAAACCAATCTGGCTTA-3) [12]; CO1 primers CO1fwd (5-AGWGGRTTTTGATCHGGNYT-3) and CO1rev (5-GGRTCAAAAAAYSTDGTRTTTA-3) [16].

All PCRs were performed in $20 \mu \mathrm{L}$ volumes containing dNTPs $0.2 \mathrm{mM}$, primers $0.8 \mu \mathrm{M}$, Taq polymerase 0.02 $\mathrm{U} / \mu \mathrm{L}, 2 \mu \mathrm{L} 10 \times$ buffer PCR and milli-Q water to achieve the correct final volume. PCR conditions for $16 \mathrm{~S}$ was as follows: denatured at $98^{\circ} \mathrm{C}$ for $2 \mathrm{~min}$, followed with 40 cycles $\left(95^{\circ} \mathrm{C}\right.$ for $30 \mathrm{~s}, 46^{\circ} \mathrm{C}$ for $30 \mathrm{~s}, 72^{\circ} \mathrm{C}$ for $\left.1 \mathrm{~min}\right)$ and final elongation $72^{\circ} \mathrm{C}$ for $5 \mathrm{~min}$. For CO1: initial denaturation at $98^{\circ} \mathrm{C}$ for $2 \mathrm{~min}$, followed with 37 cycles $\left(95^{\circ} \mathrm{C}\right.$ for $30 \mathrm{~s}, 50^{\circ} \mathrm{C}$ for $30 \mathrm{~s}, 72^{\circ} \mathrm{C}$ for $1 \mathrm{~min}$ ) and final extension at $72^{\circ} \mathrm{C}$ for $2 \mathrm{~min}$. For SSU rDNA: initial denaturation at $98^{\circ} \mathrm{C}$ $5 \mathrm{~min}$, followed with 35 cycles $\left(95^{\circ} \mathrm{C}\right.$ for $30 \mathrm{~s}, 55^{\circ} \mathrm{C}$ for 
$45 \mathrm{~s}, 72^{\circ} \mathrm{C}$ for $1 \mathrm{~min}$ ), and final extension at $72^{\circ} \mathrm{C} 7 \mathrm{~min}$. PCR amplifications were performed in an iCycler (BioRad, Hercules, CA, USA) thermocycler and the products visualised in an SYBR green stained 1.5\% agarose gel using a $100 \mathrm{bp}$ ladder (Takara) to estimate the size of the amplicons.

PCR products were purified using PCR purification or agarose gel extraction kits (Qiagen), depending on whether bands were excised from gels to reduce contamination, and used directly in sequencing reactions at the Operon Biotechnologies Company, Tokyo, Japan. Both forward and reverse directions were sequenced for all products using the same primers from the initial amplifications. DNA sequencing was performed on all positive PCR products of the expected sizes for 4 individual replicates for $P$. uniartus and 3 replicates for P. fugu. Nucleotide Basic Local Alignment Search Tool (BLAST) searches were performed for each sequence to confirm a copepod origin.

\section{Sequence alignment and phylogenetic analyses}

The sequences were analyzed using Edit Sequence of DNASTAR Lasergene version 7.2.1 and Bioedit Sequence Alignment Editor 7.0.5.3 comparing with the original chromatogram. Multiple Sequence Alignment (MSA) with all reported caligids in the GenBank was performed using software Clustal X and then edited using Bioedit.

Phylogenetic analyses were performed using the maximum likelihood methodology in PhyML [19] with the general time-reversible substitution model selected and 1000 bootstrap repeats, and Bayesian inference (BI) analysis using MrBayes v. 3.2 [20]. For the BI analysis, models of nucleotide substitution were first evaluated for the alignment using MrModeltest v. 2.2 [21]. The optimum evolutionary model based on the Akaike information criterion (AIC) was the general time-reversible GTR + $\mathrm{I}+\mathrm{G}$ model of evolution where $\mathrm{G}$ is the gamma distributed rate variation among sites and $I$ is the proportion of invariable sites. Therefore, the settings used for the analysis were nst $=6$, with the gamma-distributed rate variation across sites and a proportion of invariable sites (rates $=$ invgamma). The priors on state frequency were left at the default setting (Prset statefreqpr $=$ dirichlet $(1,1$, $1,1)$ ). Posterior probability distributions were generated using the Markov Chain Monte Carlo (MCMC) method with four chains being run simultaneously for 1000,000 generations. Burn in was set at 2500 and trees were sampled every 100 generations making a total of 7500 trees used to compile the majority rule consensus trees.

\section{Results}

\section{PCR Amplification and DNA sequencing}

PCR amplification and DNA sequencing for the three gene regions for both Pseudocaligus was successful. BLAST searches of SSU rDNA sequences of 1772 bp for $P$. fugu and $1776 \mathrm{bp}$ for P. uniartus showed high identities to Caligus elongatus (99\%) and an unidentified Caligus sp. (98\%) from rabbit fish respectively. BLAST searches of 16S mitochondrial sequences of 442 bp for $P$. fugu and 457 bp $P$. uniartus showed a much lower identity of $81 \%$ to Caligus gurnardi and $82 \%$ to Caligus centrodonti respectively and BLAST searches of CO1 mitochondrial sequences of $567 \mathrm{bp}$ for $P$. fugu and $566 \mathrm{bp}$ P. uniartus revealed an $81 \%$ identity to isolates of $C$. elongatus and an $83 \%$ identity to Caligus clemensi and C. centrodonti respectively. DNA sequences obtained in this study were submitted under the accession numbers [GenBank: KC569363-KC569368].

\section{Phylogenetic analysis of Pseudocaligus within the Caligidae}

The DNA sequences for Pseudocaligus did not group together to form a discrete monophyletic clade in any of our phylogenetic analyses. Pseudocaligus fugu was placed in a clade with $C$. elongatus in two analyses, being robustly supported in SSU rDNA analyses within the $C$. elongatus-like clade (Figures 1 and 2), well supported in the $16 \mathrm{~S}$ analysis but unresolved along with many Caligus spp. in the CO1 analysis (Figure 3A and B). Pseudocaligus brevipedis was robustly supported in a clade containing $C$. curtus and C. centrodonti in all three analyses (Figures 1 and 3), and formed a sister clade to a well supported Lepeophtheirus clade in the CO1 analysis (Figure 3B). Pseudocaligus uniartus was well supported in the Caligus clade in the SSU rDNA phylogenies but remained unresolved in all other analyses (Figure 1, Figure 3A and B).

An alignment of 31 caligid SSU rDNA sequences produced congruent topologies using maximum likelihood and Bayesian methodologies (Figure 1). The three Pseudocaligus spp. are robustly placed in the Caligus clade, although support for the overall grouping and the basal branching events in the tree are low (Figure 1). Pseudocaligus fugu is well supported as a member of the C. elongatus-like clade within the larger Caligus grouping. Pseudocaligus uniartus is well supported and forms a sister clade with Caligus sp. 1 to the C. elongatus-like clade. Pseudocaligus brevipedis is robustly supported in a clade with $C$. centrodonti and $C$. curtus that form the basal clade in the Caligus group. The majority of Lepeophtheirus spp. form a robust clade, which is a sister group to one containing other non-lunule bearing caligid genera, Paralebion and Gloiopotes, together forming a sister clade to the Caligus group. However, $L$. natalensis does not group within the main Lepeophtheirus clade and forms an unsupported branch at the base of the Caligus clade (Figure 1). During the alignment of $18 \mathrm{~S}$ sequence data an eight base pair deletion starting immediately after the motif sequence 5'AAAAAATCCCG was found to occur (Figure 2), but was only present in the 


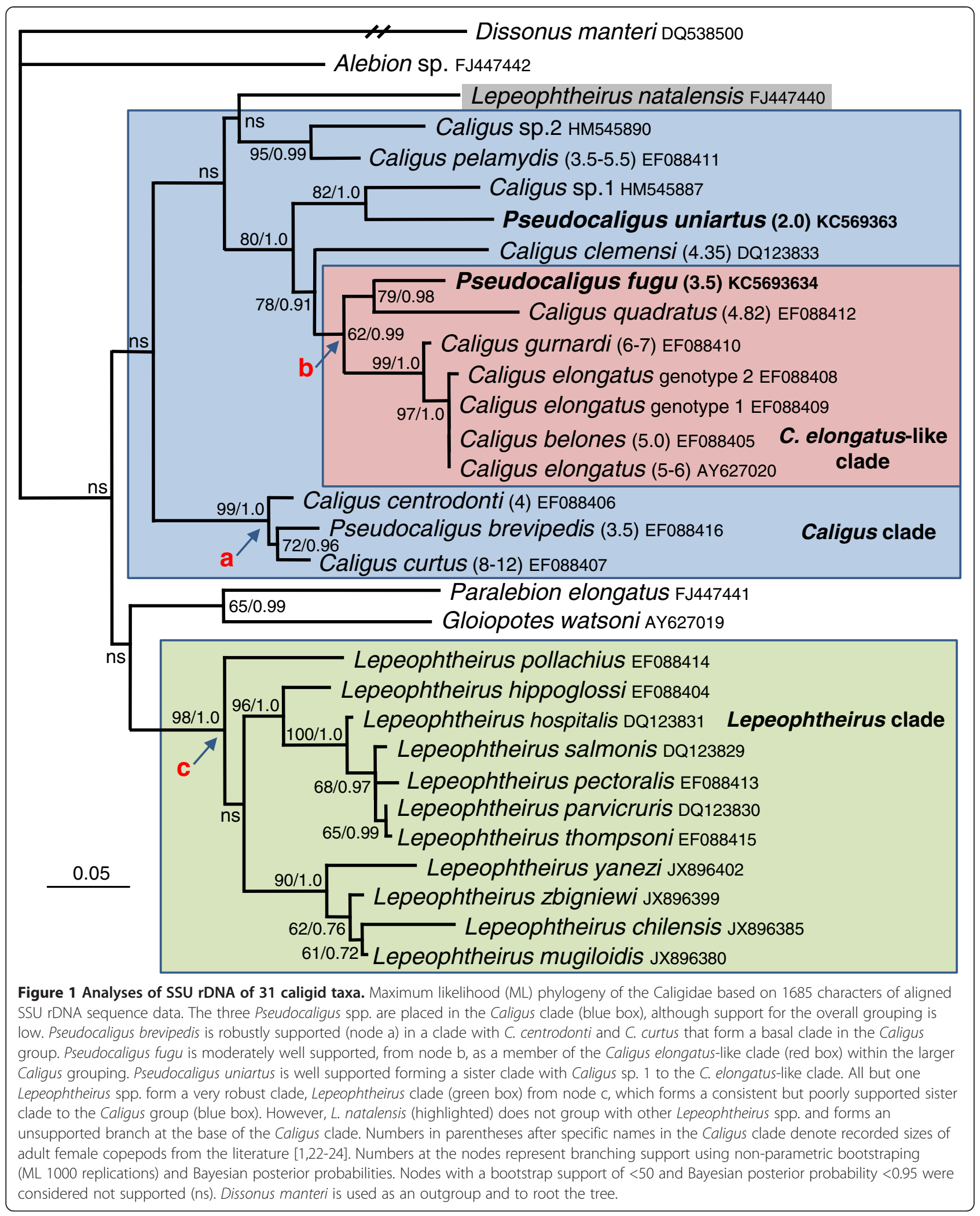

seven members of the Caligus elongatus-like clade, which includes $P$. fugu, but not the other Pseudocaligus spp. (Figure 1).

\section{Discussion}

The family of parasitic copepods, the Caligidae, comprises some 33 accepted genera [25], of which only 7 have DNA 


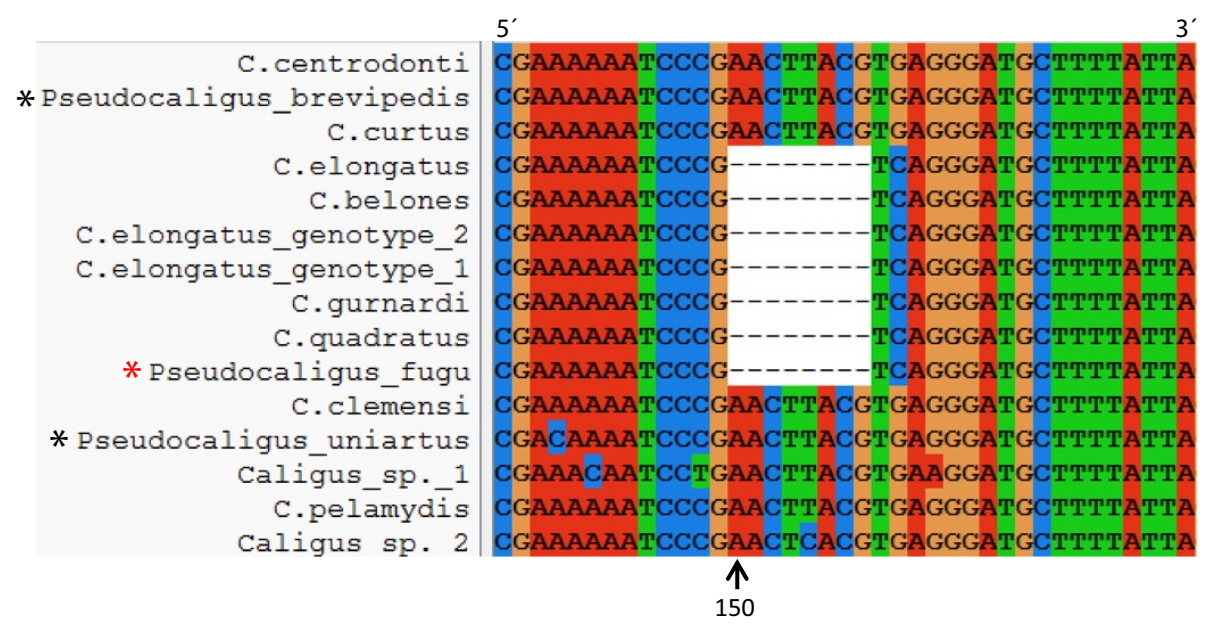

Figure 2 Synapomorphy in the SSU rDNA region of members of the C. elongatus-like clade. Part of an alignment of 18S Caligidae sequences showing an eight base pair deletion starting 150 bases from the $5^{\prime}$ end of our alignment, immediately after the motif sequence AAAAAATCCCG. This deletion is only seen in the seven members of the Caligus elongatus-like clade (red box Figure 1), which includes $P$. fugu (red asterisk), but not other Pseudocaligus spp. (black asterisk).

sequence data available that can be used to infer molecular phylogenetic relationships. It is not possible to provide a comprehensive molecular phylogeny for the family until more DNA data for the various genera become available. However, available molecular data largely come from two of the most specious genera, Caligus and Lepeophtheirus, and can be used to identify important molecular phylogenetic relationships between these related taxa. Morphologically, Lepeophtheirus differ from Caligus as they lack lunules. Lunules are paired sucker-like structures on the frontal plates that are used for attachment to the fish host, and are unique to nearly half of the genera within the Caligidae, including Caligus and Pseudocaligus [2,26]. Lunules are thought to have evolved only once in the Caligidae and character based phylogenetic analysis of the family suggests that several genera, such as Lepeophtheirus, have secondarily lost their lunules [2]. In accordance with this theory, we consistently retrieve the majority of Lepeophtheirus spp. as a separate well-supported clade in our analyses, with the lunule bearing Caligus and Pseudocaligus, grouping together as a sister taxon. However, within the lunule-bearing group, the three sequences available for Pseudocaligus are consistently placed apart from each other, and form parts of recoverable clades, that appear to reflect the geographical location and/or the fish host taxon. In the SSU rDNA analyses, P. fugu groups with Caligus quadratus also infecting fish from Japan and forms part of the C. elongatus clade; P. uniartus groups with an unidentified Caligus sp. that also infects siganid fish from Indo-Pacific region, and P. brevipedis, found on gadoid fish in the Atlantic, consistently groups with two species of Caligus from the Atlantic, one is the type species of the genus, C. curtus, which is also found on gadoid fish. Interestingly, this robustly places the type species for Pseudocaligus, P. brevipedis, together with the type species for Caligus, but suggests that the lineages strongly reflect zoogeographic history and host fish taxon rather than morphology. It is also interesting, in the SSU rDNA and CO1 analyses that Lepophtheirus natalensis, the only Lepeophtheirus sequence known solely from an elasmobranch, groups away from an otherwise well supported clade containing all Lepeophtheirus sequences from teleosts (Figures 1 and 3B) and does not group with other shark-infecting caligid species, such as Paralebion elongatus (Figure 1). This is supported by greater genetic distances (data not shown) between $L$. natalensis and other Lepeophtheirus sequences compared to other caligid genera and suggests that when more DNA data is available for the genus, that Lepeophtheirus as currently constituted and identified will not form a monophyletic group. In this study we analysed one nuclear (SSU rDNA) and two mitochondrial genes (CO1 and 16S) and found a reproducible level of congruence for some caligid taxa between the phylogenies. However, numerous nodes remain unsupported in all trees that would otherwise allow a far better inference of phylogenetic relatedness between the species and genera within the Caligidae. Whilst the inclusion of more caligid taxa will undoubtedly lead to a better resolution of phylogenetic relationships within the family, it may also be useful to seek additional gene regions that are less conserved than the SSU rDNA but not as variable as the mitochondrial genes. The $5.8 \mathrm{~S}$ region of the ribosomal RNA gene and the flanking internal transcribed spacer regions (ITS1 and ITS2) have been used successfully for some phylogenetic analyses, however, the ITS regions are known to be highly 

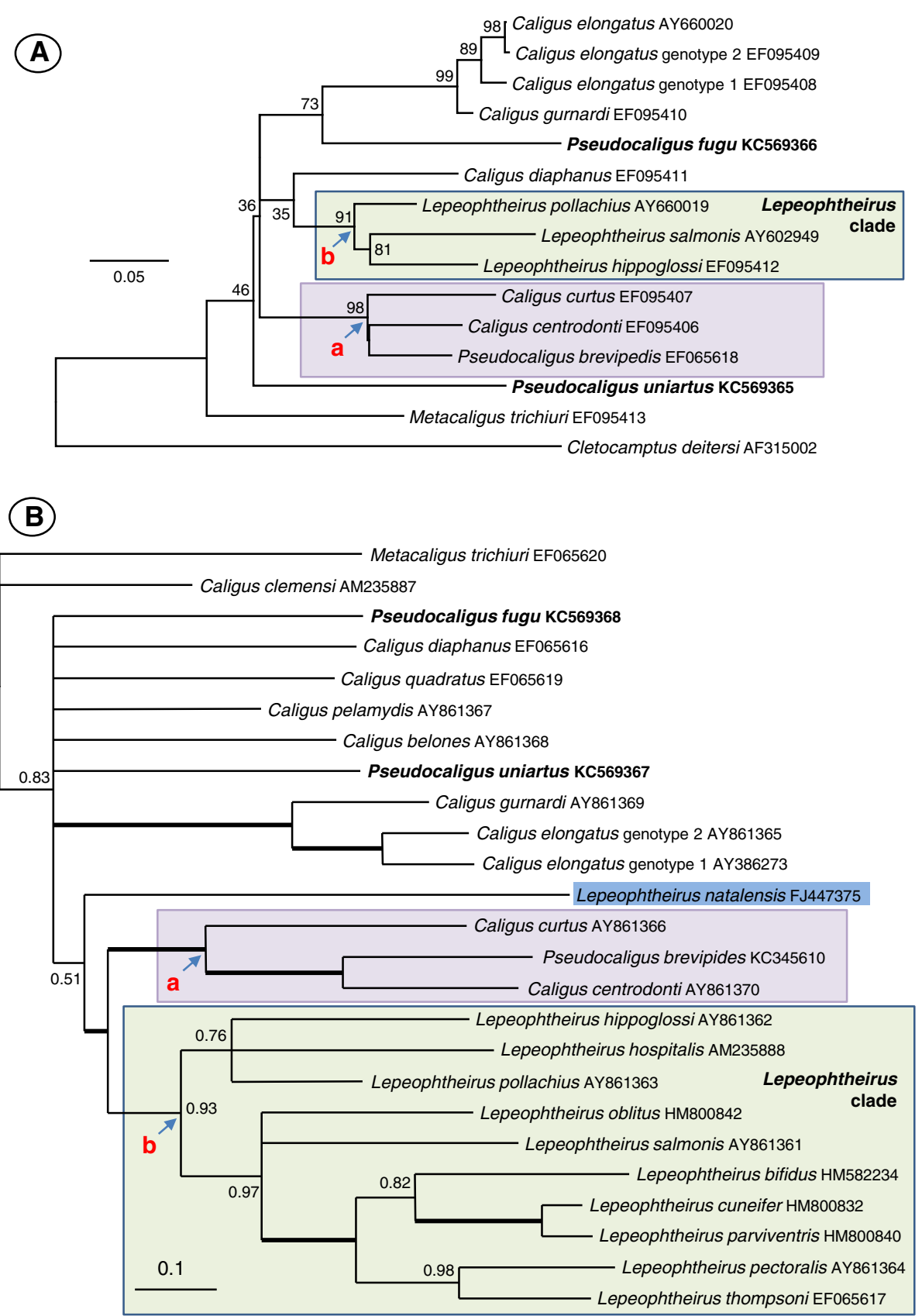

Figure 3 Phylogenetic trees of mitochondrial DNA sequence analyses for the Caligidae. A) Maximum likelihood tree constructed from analysis of 462 characters of aligned small subunit 165 ribosomal gene. B) Bayesian topology based on analysis of 528 characters of aligned CO1 genes of 25 caligid taxa. Pseudocaligus brevipedes is robustly supported in a clade with C. curtus and C. centrodonti in both analyses (node a, shaded boxes). Pseudocaligus fugu forms the basal taxon to the C. elongatus group in the 165 analysis and is unresolved in the CO1 tree. Pseudocaligus uniartus is unresolved in both analyses. Lepeophtheirus spp. form well-supported clades in both trees (node b, green boxes), apart from L. natalensis (highlighted) in the CO1 tree that is unresolved. Thick branches are from nodes with full support and figures at the nodes represent bootstrap support values from 1000 samplings for the 165 tree and posterior probabilities for the Bayesian topology.

divergent among crustaceans and may only be an appropriate marker for studies at the species or population level [27]. Potentially, utilising a concatenated set of conserved gene regions from nuclear rDNA may provide sufficient information for good resolution at the generic level for molecular systematic studies of the Caligidae.

There were only nine species of Pseudocaligus recognised (Table 1), which is considerably smaller than the number of Caligus species described, currently in excess of 240 [25]. 
Table 1 Pseudocaligus spp. (recently synonymised with Caligus [14,15]), with fish host, geographical location and sizes

\begin{tabular}{|c|c|c|c|c|}
\hline Pseudocaligus spp. & Host fish in & Geographical location & Size female $(\mathrm{mm})$ & Size male $(\mathrm{mm})$ \\
\hline P. apodus Brian, 1924 [29] & $\begin{array}{l}\text { Mugil sp. (Mugilidae) and } \\
\text { Eugaleus galeus (Triakidae) }\end{array}$ & Mauritania & $5-6$ & $\mathrm{n} / \mathrm{a}$ \\
\hline \multirow[t]{2}{*}{ P. brevipedis Bassett-Smith, 1896 (type) $[1,28]$} & Motella tricirrata & UK & 3.5 & $<$ female \\
\hline & (Lotidae, Gadiformes) & & & \\
\hline \multirow[t]{2}{*}{ P. fistulariae Pillai, 1961 [30] } & Fistularia petimba & India (Arabian Sea) & 5.1 & 3.2 \\
\hline & (Fistulariidae) & & & \\
\hline \multirow[t]{2}{*}{ P. fugu Yamaguti, 1936 [31] } & Takifugu spp. & Japan & 3.3-3.63 & \\
\hline & (Tetraodonitidae) & & & \\
\hline \multirow[t]{2}{*}{ P. indicus Hameed, 1977 [32] } & Dactyloptena orientalis & India (Arabian Sea) & 4.5 & 3.9 \\
\hline & (Dactylopteridae) & & & \\
\hline \multirow[t]{2}{*}{ P. laminatus Rangnekar, 1955 [33] } & Tetrodon oblongus & India (Arabian Sea) & 3.64 & 1.55 \\
\hline & (Tetraodonitidae) & & & \\
\hline \multirow[t]{2}{*}{ P. parvus Bassett-Smith, 1898 [34] } & Tetrodon oblongus & India (Arabian Sea) & 3.4 & 2.3 \\
\hline & (Tetraodonitidae) & & & \\
\hline \multirow[t]{2}{*}{ P. subparvus Hameed, 1977 [32] } & Arothron hispidus & India (Arabian Sea) & 3.5 & $\mathrm{n} / \mathrm{a}$ \\
\hline & (Tetraodonitidae) & & & \\
\hline $\begin{array}{l}\text { P. uniartus Ho, Kim, Cruz-Lacierda et } \\
\text { Nagasawa, } 2004 \text { [1 1] }\end{array}$ & Siganus guttatus & Philippines & 2.0 & 1.9 \\
\hline
\end{tabular}

Of these nine, the majority are found in the Indo-Pacific region except for the type species $P$. brevipedis and $P$. apodus that are found in European waters (Table 1). It is interesting that four of the seven species of Pseudocaligus from the Indo-Pacific region are found infecting puffer fish, Tetraodonitidae (Table 1). This either demonstrates an unambiguous correlation between host fish family and the evolutionary reduction of the fourth leg, or implies that the Pseudocaligus infecting puffer fish in the Indo-Pacific region have radiated from a common ancestor with a Pseudocaligus-like morphology. If the latter is the case, then we would expect Pseudocaligus from puffer fish from the Indo-Pacific to group with $P$. fugu in future molecular phylogenetic studies and to have the same synapomorphy seen in the SSU rDNA sequence (Figure 2). It is also noteworthy that there appears to be a trend toward miniaturisation in pseudocaligids (Table 1), Pseudocaligus uniartus, from the present study, being the most extreme example at only $2 \mathrm{~mm}$ in length for an adult female. However, if adult female size data is considered with respect to SSU rDNA phylogenetic placements for the type species, C. curtus and $P$. brevipedis, the opposite trend can be observed (Figure 1). Caligus curtus and P. brevipedis form a well-supported clade from node a (Figure 1), with $C$. centrodonti as the basal taxon measuring about $4 \mathrm{~mm}$ [1]. The derived taxa measure a comparable $3.5 \mathrm{~mm}$ for $P$. brevipedis [28], whilst C. curtus is significantly larger with a range of $8-12 \mathrm{~mm}$ [24]. A similar trend can be seen with $P$. fugu (from node b, Figure 1) where the derived taxa $C$. elongatus, $C$. belones and $C$. gurnardi are all larger in size [1,24]. This suggests a relationship between body length and the presence of a functional fourth leg, where in our SSU rDNA analyses the evolutionary derived species are larger and possess fully developed fourth legs. However, in the two mitochondrial gene phylogenies, the larger $C$. curtus is well supported as basal to the smaller $C$. centrodonti and $P$. brevipedis. It is apparent that the size of the fourth leg is extremely plastic within the Caligidae, and appears likely that fourth leg reduction or retention occurs readily during evolution and may be a function of adaptation to host fish or new environments, and may also be linked to body length. Additional DNA data from related caligids will be required to clarify these phylogenetic inconsistencies.

The phylogenetic distribution of the three sequenced gene regions now available for pseudocaligids indicates that the genus is polyphyletic, i.e. these species do not have a common ancestor with a reduced fourth leg. We infer that this trait evolved independently for each of the three Pseudocaligus species sequenced so far, suggesting that they have all been subjected to similar evolutionary pressures. Kabata [4] suggested that the fourth leg has become largely, if not entirely, non-functional, and plays no discernible role in locomotory activities, and therefore it would atrophy. Indeed, similar traits are also observed in other caligid genera; Pseudolepeophtheirus contains a copepod with vestigial fourth leg appendages and in the genus Markevichus they have been completely lost. The development of the fourth leg is similar in Caligus and Lepeophtheirus, first appearing as rudimentary and lobate at the first chalimus and developing to a ventrolaterally 
paired anlagen of the fourth leg by the second chalimus and being a fully developed uniramus appendage prior to the final molt to adult [13]. However, in Pseudocaligus, the fourth leg first appears at the second chalimus and is suppressed from then, never fully developing [9]. Although reduction or loss of the fourth leg is neither an isolated nor a phylogenetically related occurrence, it is still only apparent in the minority of described caligids. Retention of the fourth leg in the majority of the Caligidae suggests that they are still functional and may be important for ease of movement on fish hosts in larger caligids.

Arthropods exhibit remarkable body plan diversity that includes variation in the number, shape, and size of limbs, with crustaceans having a higher degree of appendage specialization than any other animal group [35]. Several studies have demonstrated that evolutionary changes in arthropod body plan are linked to changes in the expression of Hox genes [36] including the Ultrabithorax ( $U b x)$ gene in the arrangement of distinct thoracic appendage identities in crustaceans [37]. Therefore, it is plausible that during caligid evolution, changes in the Hox gene have resulted in a reduction of thoracic limbs to occur in parallel in different populations of parasitic copepods.

In their molecular phylogenetic studies of the Caligidae, Øines and Shram [12] also found that P. brevipedis was closely associated with Caligus spp. in contrast to the character-based study of Ho and Lin [2], where Pseudocaligus was estimated to be more distant to the genus Caligus. They proposed on the basis of their molecular phylogenetic data that $P$. brevipedis should be included into the genus Caligus based on its close association with C. curtus, C. centrodonti, and other Caligus species. Other researchers, on the basis of morphology and developmental features, also expressed doubts about the validity of Pseudocaligus [1,13]. Kabata [1] believed that both the genera Pseudolepeophtheirus and Pseudocaligus should be synonymized with their parent genera, and highlighted the fact that another caligid genus, Pseudoanuretes, contains taxa with both normal and vestigial fourth legs, indicating that reduction was not an anomalous trait within the Caligidae. Our data confirms and supports this consensus of opinion, that Pseudocaligus is not a valid genus in the Caligidae.

\section{Conclusions}

We have demonstrated, with molecular phylogenetic studies of caligid copepods, that pseudocaligids group with other lunule bearing copepods from the genus Caligus, but they have a polyphyletic distribution within the group, and tend to group with geographically related Caligus spp. or with those infecting related host fish. We infer that the reduction of the fourth leg has evolved independently on multiple occasions in the Caligidae and is an example of convergent or parallel evolution within a related group of organisms. Therefore, we support the synonymy of Pseudocaligus with Caligus.

\section{Competing interests}

The authors declare that they have no competing interests.

\section{Authors' contributions}

HA and MAF carried out the molecular part of the study and phylogenetic analyses. KO collated the publication history and taxonomic information. $\mathrm{MAF}, \mathrm{HA}$ and $\mathrm{KO}$ all helped to prepare the manuscript and were all agreed upon the final version.

\section{Acknowledgements}

This research was supported by the Directorate of Higher Education, Ministry of National Education of Indonesia, through the Academic Recharging Program and a University of Malaya HIR grant (UM.C/625/1/HIR/138). We would like to thank Professor Geoff Boxshall from the Natural History Museum in London for his critical assessment of this manuscript, Dr T. Chad Walter from the Smithsonian Institution for sending copies of reference papers and members of The Fish Diseases Laboratory from The University of Tokyo, for their cooperation.

\section{Author details}

${ }^{1}$ Institute of Ocean and Earth Sciences, University of Malaya, Kuala Lumpur, Malaysia. ${ }^{2}$ Department of Fisheries, Laboratory of Fish Parasites and Diseases, Faculty of Marine Sciences and Fisheries, Hasanuddin University, Makassar, Indonesia. ${ }^{3}$ Meguro Parasitological Museum, 4-1-1, Shimomeguro, Meguro-ku, Tokyo 153-0064, Japan.

Received: 26 September 2013 Accepted: 25 November 2013

Published: 28 November 2013

\section{References}

1. Kabata Z: Parasitic Copepoda of British fishes. London: The Ray Society; 1979

2. Ho JS, Lin CL: Sea Lice of Taiwan (Copepoda: Siphonostomatoida: Caligidae). Keelung, Taiwan: The Sueichan Press; 2004.

3. Ólafsdóttir D, Shinn AP: Epibiotic macrofauna on common minke whales, Balaenoptera acutorostrata Lacépède, 1804, in Icelandic waters. Parasit Vectors 2013, 6:105.

4. Kabata Z: Some evolutionary trends in caligid copepods. Hydrobiologia 1988, 167/168:617-622.

5. Johnson SC, Treasurer JW, Bravo S, Nagasawa K, Kabata Z: A review of the impact of parasitic copepods on marine aquaculture. Zool Stud 2004, 43:229-243

6. Costello MJ: Review of methods to control sea lice (Caligidae: Crustacea) infestations on salmon (Salmo salar) farms. In Pathogens of Wild and Farmed Fish: Sea Lice. Edited by Boxshall GA, Defaye D. Chichester: Ellis Horwood; 1993:219-252.

7. Horsberg TE: Avermectin use in aquaculture. Curr Pharm Biotechnol 2012, 13:1095-1102

8. Costello MJ: The global economic cost of sea lice to the salmonid farming industry. J Fish Dis 2009, 32:115-118.

9. Ohtsuka S, Takami I, Venmathi Maran BA, Ogawa K, Shimono T, Fujita Y, Asakawa M, Boxshall GA: Developmental stages and growth of Pseudocaligus fugu Yamaguti, 1936 (Copepoda: Siphonostomatoida: Caligidae) host-specific to puffer. J Nat Hist 2009, 43:1779-1804.

10. Freeman MA, Ogawa K: Variation in the small subunit ribosomal DNA confirms that Udonella (Monogenea: Udonellidae) is a species-rich group. Int J Parasitol 2010, 40:255-264.

11. Ho JS, Kim IH, Cruz-Lacierda ER, Nagasawa K: Sea lice (Copepoda: Caligidae) of marine cultured and wild fishes in the Philippines. J Fish Soc Taiwan 2004, 31:235-249.

12. Øines O, Schram T: Intra- or inter-specific difference in genotypes of Caligus elongatus Nordmann 1832. Acta Parasitol 2008, 53:93-105.

13. Venmathi Maran BA, Moon SY, Ohtsuka S, Oh SY, Soh HY, Myoung JG, Iglikowska A, Boxshall GA: The caligid life cycle: new evidence from Lepeophtheirus elegans reconciles the cycles of Caligus and Lepeophtheirus (Copepoda: Caligidae). Parasite 2013, 20:15.

14. Dojiri M, Ho JS: Systematics of the Caligidae, copepods parasitic on marine fishes. Crustaceana Monographs 2013, 18:1-448. 
15. Özak AA, Demirkale I, Boxshall GA, Etyemez M: Parasitic copepods of the common sole, Solea solea (L.), from the Eastern Mediterranean coast of Turkey. Syst Parasitol 2013, 86:173-185.

16. Øines O, Heuch PA: Identification of sea louse species of the genus Caligus using mtDNA. J Mar Biol Ass UK 2005, 85:73-79.

17. Freeman MA, Yokoyama H, Ogawa K: A microsporidian parasite of the genus Spraguea in the nervous tissues of the Japanese anglerfish Lophius litulon. Folia Parasitol 2004, 51:167-176.

18. Hillis DM, Dixon MT: Ribosomal DNA: molecular evolution and phylogenetic inference. Q Rev Biol 1991, 66:411-453.

19. Guindon S, Dufayard JF, Lefort V, Anisimov M, Hordijk W, Gascuel O: New algorithms and methods to estimate maximum-likelihood phylogenies: assessing the performance of PhyML 3.0. Syst Biol 2010, 59:307-321.

20. Ronquist F, Huelsenbeck JP: MrBayes 3: Bayesian phylogenetic inference under mixed models. Bioinformatics 2003, 19:1572-1574.

21. Nylander JAA, Ronquist F, Huelsenbeck JP, Nieves-Aldrey JL: Bayesian phylogenetic analysis of combined data. Syst Biol 2004, 53:47-67.

22. Parker RR, Margolis L: A new species of parasitic copepod, Caligus clemensi sp. nov. (Caligoida, Caligidae) from pelagic fishes in the coastal waters of British Columbia. J Fish Res Board Can 1964, 21:873-889.

23. Shiino SM: Note on Caligus quadratus n. sp., a copepod parasitic on the fish, Neothynnus macropterus. B Jpn Soc Sci Fish 1954, 20:26-29.

24. Yamaguti S: Parasitic Copepoda and Branchiura of Fishes. New York: Interscience Publishers; 1963

25. WoRMS Editorial Board: World Register of Marine Species. 2013. Available from http://www.marinespecies.org at VLIZ

26. Kaji T, Venmathi Maran BA, Kondoh Y, Ohtsuka S, Boxshall GA, Tsukagoshi A: The lunule of caligid copepods: an evolutionarily novel structure. Evol Dev 2012, 14:465-475.

27. Chu KH, Li CP, Ho HY: The first internal transcribed spacer (ITS-1) of ribosomal DNA as a molecular marker for phylogenetic and population analyses in Crustacea. Mar Biotechnol 2001, 3:355-361.

28. Bassett-Smith PW: Notes on the parasitic Copepoda of fish obtained at Plymouth, with descriptions of new species. Ann Mag Nat Hist 1896, 18(6):8-16.

29. Brian A: Copepoda. In: Parasitologia Mauritanica. Matérieux pour la faune parasitologique en Mauritanie. Bull Com Etud Hist Sci Afr Occid Fr 1924, 1:12-35.

30. Pillai NK: Copepods parasitic on South Indian fishes. Part 1, Caligidae. Bull Cent Res Inst Univ Kerala Ser C 1961, 8:87-130.

31. Yamaguti S: Parasitic copepods from fishes of Japan. Pt. 2. Caligoida. 1936, 1:1-22.

32. Hameed MS: Description of two new species of Pseudocaligus (copepoda, caligidae) from Kerala, India. Crustaceana 1977, 33:61-69.

33. Rangnekar MP: Pseudocaligus laminatus sp. nov. and Diphyllogaster aliuncus sp. nov. (Copepoda), parasitic on Bombay fishes. J Univ Bombay 1955, 23:43-52.

34. Bassett-Smith PW: Some new parasitic copepods found on fish at Bombay. Ann. Mag. Nat. Hist 1898, 1(7):1-17.

35. Brusca RC, Brusca GJ: Invertebrates. Sunderland MA: Sinauer Associates; 1990.

36. Pavlopoulos A, Kontarakis Z, Liubicich DM, Serano JM, Akam M, Patel NH, Averof M: Probing the evolution of appendage specialization by Hox gene misexpression in an emerging model crustacean. Proc Nat Acad Sci USA 2009, 106:13897-13902.

37. Averof $\mathrm{M}$, Patel $\mathrm{NH}$ : Crustacean appendage evolution associated with changes in Hox gene expression. Nature 1997, 388:682-686.

\section{Submit your next manuscript to BioMed Central and take full advantage of:}

- Convenient online submission

- Thorough peer review

- No space constraints or color figure charges

- Immediate publication on acceptance

- Inclusion in PubMed, CAS, Scopus and Google Scholar

- Research which is freely available for redistribution 